\title{
Isoflavone Aglycones and Oligopeptides in Lactic Acid-Fermented Soy Milk Differentially Regulate Lipid Metabolism-Related Gene Expression
}

\author{
Maki Kobayashi ${ }^{*}$, Shintaro Egusa ${ }^{2}$, Mitsuru Fukuda3 \\ ${ }^{1}$ Department of Nutritional Management, School of Health Science, Hyogo University, Kakogawa, Japan \\ ${ }^{2}$ Research Institute, Marusan-Ai Co., Ltd., Okazaki, Japan \\ ${ }^{3}$ Research Institute for Nutrition Sciences, Mukogawa Women’s University, Nishinomiya, Japan \\ Email: ^makik@hyogo-dai.ac.jp, Shintaro.egusa@marusanai.co.jp,senjuoka@mukogawa-u.ac.jp
}

How to cite this paper: Kobayashi, M., Egusa, S. and Fukuda, M. (2016) Isoflavone Aglycones and Oligopeptides in Lactic AcidFermented Soy Milk Differentially Regulate Lipid Metabolism-Related Gene Expression. Food and Nutrition Sciences, 7, 989-1009. http://dx.doi.org/10.4236/fns.2016.711097

Received: August 4, 2016

Accepted: September 20, 2016

Published: September 23, 2016

Copyright $\odot 2016$ by authors and Scientific Research Publishing Inc. This work is licensed under the Creative Commons Attribution International License (CC BY 4.0).

http://creativecommons.org/licenses/by/4.0/ c) (i) Open Access

\section{Abstract}

We previously investigated the physiological effect of an ethanol extract of fermented soymilk on rats and clarified that this extract modulated their hepatic lipid metabolism. Although the soy isoflavones and oligopeptides are representative functional components of the ethanol extract, it remained unclear whether these substances share a role in lipid metabolism modulation. Therefore, we attempted to clarify the effects of isoflavones and oligopeptides in lactic acid-fermented soymilk on lipid metabolism-related gene expression in rats and HepG2 cells. The fermented soymilk extract had a higher isoflavone aglycone content than the soymilk extract. Sevenweek-old male Sprague-Dawley rats were fed an AIN-93G diet, a diet plus $70 \%$ soymilk ethanol extract, or a diet plus $70 \%$ fermented soymilk ethanol extract for 5 weeks. Although both the soymilk and fermented soymilk ethanol extracts did not significantly affect plasma and hepatic lipid profiles, the expression levels of the genes encoding CYP7a1 and SREBP-2 were significantly upregulated in the livers of rats fed with the fermented soymilk extract. Whereas isoflavone aglycones upregulated CYP7a1-encoding gene expression in HepG2, oligopeptides in soymilk and fermented soymilk downregulated this expression. Oligopeptides in fermented soymilk downregulated the expression stronger than that observed with soymilk. On the other hand, no significant change in FAS expression was observed in the livers of rats fed the fermented soymilk extract. Although isoflavone aglycones did not affect FAS expression in HepG2 cells, oligopeptides in fermented soymilk downregulated FAS expression. The downregulation of FAS with oligopeptides from fermented soymilk was stronger than that from soymilk. In the present animal experiment, the effect on reduction of fat synthesis was not found because of insufficient amount of peptides derived from digestion of soy protein. These results suggest that isoflavone aglycones 
increase CYP7al gene expression, whereas oligopeptides decrease FAS expression. Isoflavone glycosides and proteins in soymilk were converted to isoflavone aglycones and oligopeptides by lactic acid fermentation, respectively, and these functional components independently improved the lipid metabolism. In the present study, it was found that isoflavone aglycones and oligopeptides in fermented soymilk differentially regulate hepatic lipid metabolism-related gene expression. Therefore, the consumption of fermented soymilk containing isoflavone aglycones and soy oligopeptides might prevent dyslipidemia more effectively than that of any other soy food. Fermented soymilk is a superior functional food modulating lipid metabolism.

\section{Keywords}

Isoflavone, Oligopeptide, Fermented Soymilk, Lipid Metabolism

\section{Introduction}

Soy-based foods are well known to prevent hypercholesterolemia [1]. Soy protein and isoflavone are the major bioactive components in these foods. Soy protein reduces cholesterol levels by inhibiting cholesterol absorption in the intestines and promoting fecal excretion through bile acid binding [2]-[4]. Soy protein reduces plasma low-density lipoprotein cholesterol (LDL-C) levels [1] [5]. Furthermore, $\beta$-conglycinin, an active soy protein component, can reduce plasma triglyceride (TG) levels and body fat mass [6]. On the other hand, isoflavones are known to be effective against obesity [7]. Genistein, an isoflavone, was shown to reduce adipose deposition in a dose-dependent manner [8]. Moreover, genistein and daidzein were found to modulate hepatic glucose and lipid metabolism [9] [10]. The lipid metabolism-modulating effects of combined isoflavones and soy protein have been reported through clinical analyses and meta-analyses [11][14].

Although soymilk, the simplest soy food, is easily prepared, its taste is generally considered unfavorable. Accordingly, we used soymilk fermented by lactobacilli of vegetable origin to increase the palatability. Lactic acid fermentation converts isoflavone glycosides in soymilk to isoflavone aglycones [15], thus enhancing their absorption in the intestine [16]. We previously reported the lipid metabolism-modulating effects of fermented soymilk in rats fed an AIN-93G diet [17], a high-cholesterol diet [18], a highfat diet [19], and a high-fat and high-cholesterol diet [20] [21]. Additionally, an increase in the amount of isoflavone aglycones in fermented soymilk enhances this lipid metabolism-modulating effect [21]. Although we found that the administration of only isoflavone aglycone fraction from fermented soymilk did not improve lipid metabolism in rats fed a high-cholesterol diet, isoflavone aglycon fraction improved lipid metabolism when given together with soy protein [22]. However, the isoflavone fraction used in our pervious paper, ethanol extract from fermented soymilk, contained both isoflavone aglycones and soy peptides [22]. Peptides and protein hydrolysates reportedly exhibit greater bioactivities relative to intact proteins or amino acid mixtures [3] [23]. Many 
peptides prepared from both plant and animal sources exhibit multiple bioactivities, such as the antihypertensive peptides IAP and VY [24], the hypocholesteromic wheat gliadin-derived peptide IIARK [25], sardine muscle [26], and bovine milk $\alpha$-lactoglobulin [27] [28]. Black soybean peptide and brown rice peptide are also known to exert lipid metabolism-modulating effects [29] [30]. Di- and tri-peptides are absorbed faster than amino acids because the human intestine expresses the oligopeptide transporter Pept-1 [31] [32]. Additionally, soy peptide is easily absorbed by the intestine in human [33], and bioactive peptides, especially soy-derived tri- or tetra-peptides, migrate through the bloodstream without degradation in human [34] and rats [35]. Furthermore, several bioactive peptides, including the hypocholesterolemic peptide LPYPR anti-hypertensive peptide NWGPLV, antioxidant peptide LLPHH, and anti-obesity peptide VRIRLLQRFNKRS were found to be derived from soy protein, of which the major constituents were glycinin and $\beta$-conglycinin in rodents or in vitro [36]-[38]. Additionally, soymophin-5, a soy-protein derived peptide, was shown to reduce glucose and TG concentrations in mice [39]. Another report described a hypotriglyceridemic di-peptide derived from soy protein in HepG2 cells and rats [40]. Moreover, a soy peptide derived from $\beta$-conglycinin induced a lipid metabolism-modulating effect in a hepatic cell line [41] and inhibited lipid accumulation in adipocytes [42].

Most lipid metabolism-modulating peptides appear to be di-, tri-, or oligopeptides, as these are more easily absorbed in the intestine. It is therefore assumed that soy peptides, especially those with a molecular weight $<1 \mathrm{kDa}$, exert lipid metabolism-modulating effects. We previously reported that the isoflavone aglycone fraction from fermented soymilk was not sufficient to improve lipid metabolism in rats fed a highcholesterol diet [22]. However, the mechanism by which fermented soymilk ethanol extract, mixture of soy oligopeptides and isoflavone aglycones, affects lipid metabolism in rats fed an AIN-93G diet remains unclear. Therefore, the independent effects of isoflavone aglycones and soy peptides (especially those $<1 \mathrm{kDa}$ ) on hepatic gene expression should be resolved.

In the present study, the effect of a fermented soymilk ethanol extract on hepatic lipid metabolism-related gene expression was investigated in rats fed an AIN-93G diet. Subsequently, the effects of isoflavone aglycones and soy oligopeptides on lipid metabolism-related gene expression in HepG2 cells were investigated to clarify the independent roles of isoflavones and oligopeptides in fermented soymilk.

\section{Materials and Methods}

\subsection{Separation of Oligopeptides $<1 \mathrm{kDa}$}

Soymilk and fermented soymilk were diluted in a 1:1 ratio with distillated water, adjusted to $\mathrm{pH} 4.5$, and centrifuged to collect the supernatants. Next, $70 \%$ ethanol extracts were prepared from the supernatants to yield soymilk and fermented soymilk peptides. Cation exchange chromatography was performed using an AG-50W (Bio-Rad, Tokyo, Japan) to separate oligopeptides $<1 \mathrm{kDa}$ from the extracts. The amounts of separated peptides were measured using a Micro $\mathrm{BCA}^{\mathrm{Tm}}$ Protein Assay kit (Thermo Scientific, 
Yokohama, Japan).

\subsection{Diet}

Freeze-dried soymilk was used for the animal experiments. Fermented soymilk was prepared via lactic acid fermentation for $15 \mathrm{~h}$ with the Lactobacillus delbrueckii subsp. delbrueckii strain TUA4408L, followed by immediate freeze-drying prior to the animal experiments. The isoflavone/peptide-containing fraction extracted from soymilk using $70 \%$ ethanol (SE) was prepared, evaporated to remove ethanol, and immediately freezedried. The isoflavone/peptide-containing fraction extracted from fermented soymilk using $70 \%$ ethanol (FSE) was similarly collected. The compositions of SE and FSE are shown in Table 1. The proportions of aglyconized isoflavones in SE and FSE were 2.8\% and $84.7 \%$, respectively (Table 2). Other feed materials were purchased from CLEA Japan (Tokyo, Japan) and Wako Pure Chemical Industries (Osaka, Japan). The composition of the experimental diets is shown in Table 3.

\subsection{Animals}

Eighteen male Sprague-Dawley rats (age: 7 weeks) were purchased from Nihon SLC (Hamamatsu, Japan) and individually housed in cages at a temperature of $23^{\circ} \mathrm{C} \pm 1{ }^{\circ} \mathrm{C}$ and humidity level of $55 \% \pm 7 \%$ with a 12 -h light-dark cycle. All rats were acclimated on an AIN-93G diet for 1 week to stabilize their metabolic conditions before the feeding experiments. In our previous paper [17], a fermented soymilk diet containing a final soy protein concentration of $10 \%$ enhanced lipid metabolism in rats fed an

Table 1. Composition and energy of freeze-dried soymilk and fermented soymilk extracts.

\begin{tabular}{ccccc}
\hline & \multicolumn{2}{c}{ Soymilk extract } & \multicolumn{2}{c}{ Fermented soymilk extract } \\
\cline { 2 - 5 } Component & $(\%)$ & $\begin{array}{c}\text { Energy } \\
(\mathrm{kcal} / 100 \mathrm{~g})\end{array}$ & $(\%)$ & $\begin{array}{c}\text { Energy } \\
(\mathrm{kcal} / 100 \mathrm{~g})\end{array}$ \\
\hline Water & 4.7 & - & 4.7 & - \\
Protein & 7.1 & 28.4 & 9.6 & 38.4 \\
Fat & 13.0 & 117.0 & 18.4 & 165.6 \\
Carbohydrate & 60.6 & 242.4 & 42.1 & 168.4 \\
Dietary fiber & 0.0 & 0.0 & 0.0 & 0.0 \\
Minerals & 14.6 & - & 25.2 & - \\
Total energy & - & 387.8 & - & 372.4 \\
\hline
\end{tabular}

Table 2. Isoflavone amounts in experimental diets (isoflavone aglycone/100g).

\begin{tabular}{ccc}
\hline Ingredient & \multicolumn{2}{c}{ Diet group } \\
\cline { 2 - 3 } & SE & FSE \\
\hline Total isoflavone (mg) & 31.8 & 28.8 \\
Total isoflavone aglycone (mg) & 0.9 & 24.4 \\
Aglycone ratio (\%) & 2.8 & 84.7 \\
\hline
\end{tabular}


Table 3. Composition of the experimental diets.

\begin{tabular}{|c|c|c|c|}
\hline \multirow{2}{*}{ Ingredient } & \multicolumn{3}{|c|}{ Diet group } \\
\hline & C: AIN-93G* & SE & FSE \\
\hline Casein $^{1}(\%)$ & 20.0 & 19.6 & 19.3 \\
\hline Cornstarch $^{1}(\%)$ & 39.8 & 37.3 & 37.6 \\
\hline Dextrinized cornstarch ${ }^{1}(\%)$ & 13.2 & 12.5 & 12.7 \\
\hline Sucrose $^{1}(\%)$ & 10.0 & 10.0 & 10.0 \\
\hline Soybean oil ${ }^{1}(\%)$ & 7.0 & 6.6 & 6.4 \\
\hline Cellulose $^{1}(\%)$ & 5.0 & 5.0 & 5.0 \\
\hline Mineral mix (AIN-93G-MX) ${ }^{1}(\%)$ & 3.5 & 3.5 & 3.5 \\
\hline Vitamin mix $($ AIN-93-VX)1 (\%) & 1.0 & 1.0 & 1.0 \\
\hline L-Cystine ${ }^{2}(\%)$ & 0.3 & 0.3 & 0.3 \\
\hline Choline bitartrate $^{3}(\%)$ & 0.25 & 0.25 & 0.25 \\
\hline tert-Butylhydroquinone ${ }^{2}(\%)$ & 0.0014 & 0.0014 & 0.0014 \\
\hline Soymilk Extract ${ }^{4}$ & 0.0 & 4.0 & 0.0 \\
\hline Fermented Soymilk Extract ${ }^{4}(\%)$ & 0.0 & 0.0 & 4.0 \\
\hline Total (\%) & 100.0 & 100.0 & 100 \\
\hline Energy (kcal/100g) & 372.2 & 371.0 & 369.1 \\
\hline
\end{tabular}

C, control; SE, $4 \%$ of the control diet was replaced with soymilk extract; FSE, $4 \%$ of the control diet was replaced with fermented soymilk extract; ${ }^{1}$ CLEA Japan, Osaka, Japan; ${ }^{2}$ Wako Pure Chemical Industries, Osaka, Japan; ${ }^{3}$ Nacalai Tesque, Kyoto, Japan; ${ }^{4}$ Marusan-Ai, Okazaki, Japan; ${ }^{*}$ AIN-93G diet [43].

AIN-93G diet; in that study, the isoflavone concentration was approximately $30 \mathrm{mg} / 100$ g diet. In the present study, therefore, the soymilk or fermented soymilk ethanol extract containing the isoflavone fraction was administrated to rats at a concentration of $30 \mathrm{mg}$ isoflavone/100g diet.

The rats were initially assigned to three groups $(n=18)$ such that there were no significant differences with regard to body weight and total serum cholesterol concentration among the groups. The control (C) group was fed an AIN-93G diet. The SE- and FSE-feeding groups (SE and FSE groups, respectively) were fed a diet in which $4 \%$ of the control diet was replaced with SE or FSE, respectively (Table 3). Table 2 presents a comparison of the isoflavone concentrations in each diet. The rats were fed the respective diets and were permitted ad libitum access to their diet and water. Food intake and body weight were measured as described in our previous paper [18]. Blood and liver analyses were also performed as previously described [18]. These animal experiments were performed according to the guidelines of the Animal Use Committee of Mukogawa Women's University, and the experiments were approved by the Committee for the Care and Use of Laboratory Animals at Mukogawa Women's University (code: P2014013).

\subsection{Measurement of Plasma and Liver Metabolic Parameters}

Plasma total cholesterol (TC) and triglyceride (TG) levels were measured enzymatically 
using commercial kits (Cholesterol E-test and Triglyceride E-test, respectively; Wako Pure Chemical Industries, Osaka, Japan). Hepatic lipids were extracted according to the method described by Folch et al. [44]. Hepatic cholesterol and TG concentrations were determined enzymatically as described above.

\subsection{Real-Time Reverse Transcription-Polymerase Chain Reaction (RT-PCR) Analysis of Rat Liver}

The mRNA expression levels were quantitatively measured via real-time RT-PCR on an Applied Biosystems 7500 thermocycler (Applied Biosystems, Foster City, CA, USA), using related reagent kits according to the manufacturer's protocol. Total RNA was extracted from liver tissues with the RNeasy Mini kit (Qiagen, Valencia, CA, USA). Complementary DNA (cDNA) was synthesized from mRNA using the Prime Script ${ }^{\oplus}$ RT Reagent Kit with gDNA Eraser (Perfect Real Time; TAKARA BIO Inc., Shiga, Japan). The following inventoried TaqMan ${ }^{\circledR}$ Gene Expression Assays were used as real-time PCR primer sets: Rn01495769_ml for Srebf1 (mRNA of sterol regulatory elementbinding protein 1 (SREBP-1)), Rn00569117_ml for Fasn (mRNA of fatty acid synthase (FAS)), Rn00573474_ml for Acaca (mRNA of acetyl-CoA carboxylase (ACC)), Rn00581185_ml for Nr1h3 (mRNA of liver X receptor (LXR $\alpha$ )), Rn01502638_ml for Srebf2 (mRNA of sterol regulatory element-binding protein 2 (SREBP-2)), Rn00565598_ml for Hmgcr (mRNA of 3-hydroxy-3-methylglutaryl-CoA reductase (HMG-CR)) and Rn00564065_ml for CYP7a1 (mRNA of cytochrome p450 family 7 subfamily a polypeptide 1 (CYP7a1)) (Applied Biosystems). Rn99999916_s1 (GAPDH) was used as an endogenous control. Real-time PCR was performed with the TaqMan ${ }^{\oplus}$ Universal PCR Master Mix (Applied Biosystems). Data were normalized to GAPDH RNA expression, and fold-changes were presented as ratios relative to the control group.

\subsection{Measurement of Isoflavones in the Diet and Liver}

To measure isoflavones, the diet and liver tissue were subjected to extraction with $70 \%$ ethanol at room temperature for $24 \mathrm{~h}$ and centrifuged at $10,000 \mathrm{~g}$ for $30 \mathrm{~min}$ at room temperature. The liver had been previously deconjugated by $\beta$-glucuronidase (SigmaAldrich, Tokyo, Japan). The supernatants were collected and filtered through cellulose acetate membranes (Tosoh, Tokyo, Japan). Isoflavones in the diet and liver were analyzed using a HPLC apparatus (Tosoh) equipped with an ODS-80Ts column. HPLC was performed via gradient elution of acetonitrile from $5 \%$ to $20 \%$, using solvents of sodium acetate $(\mathrm{pH} 4.8)$-methanol (80:20) and sodium acetate ( $\mathrm{pH} 4.8)$-methanolacetonitrile (40:20:20).

\subsection{Cell Culture}

HepG2 human hepatoblastoma cells were maintained in Dulbecco's Modified Eagle Medium (DMEM) containing 10\% heat-inactivated fetal bovine serum (FBS), 100 units $/ \mathrm{ml}$ penicillin, and $100 \mu \mathrm{g} / \mathrm{ml}$ streptomycin in an atmosphere of $95 \%$ air $-5 \% \mathrm{CO}_{2}$ at $37^{\circ} \mathrm{C}$. On day $0,4.0 \times 10^{5}$ cells were plated in $60-\mathrm{mm}^{2}$ dishes. On day 1 , the medium 
was replaced with serum-free medium with antibiotics. On day 2, cells were treated with isoflavones (Sigma-Aldrich) or oligopeptides. Following 24-h incubation, total RNA was isolated from the cells using the RNeasy Mini kit (Qiagen).

\subsection{Real-Time Reverse Transcription-Polymerase Chain Reaction (RT-PCR) Analysis of HepG2 Cells}

mRNA expression was quantitatively measured by real-time RT-PCR as described in Section 2.5. Total RNA extraction and cDNA synthesis were also performed as described in Section 2.5. The following inventoried TaqMan ${ }^{\circledR}$ Gene Expression Assays were used as real-time PCR primer sets: Hs01088691_m1 for SREBP1 (mRNA of SREBP-1), Hs00188012_m1 for FASN (mRNA of FAS), Hs00172885_m1for NR1H3 (mRNA of LXR $\alpha$ ), Hs00190237_m1 for SREBP2 (mRNA of SREBP-2), Hs01092525_m1 for LDLR (mRNA of low-density lipoprotein receptor (LDLR)), and Hs00167982_m1 for CYP7a1 (Applied Biosystems). Hs02758991_g1 (GAPDH) was used as an endogenous control. Real-time PCR was performed using TaqMan ${ }^{\circledR}$ Universal PCR Master Mix (Applied Biosystems). Data were normalized to GAPDH RNA expression, and fold changes were presented as ratios relative to the control.

\subsection{Statistical Analysis}

For animal experiments, results are presented as means \pm standard errors after calculation using Microsoft Office Excel 2013 and were analyzed using Tukey's multiple comparison with a $p$ value of $<0.05$ indicating significance. For cell culture assays, results are presented as means \pm standard deviations after calculation using Microsoft Office Excel 2013 and were analyzed using Student's $t$-test. SPSS 12.0 J for Windows (SPSS, Inc., Chicago, IL, USA) was used for the statistical analyses.

\section{Results}

\subsection{Body Weight, Food Intake, Food Efficiency, and Tissue Weights}

No significant differences in initial and final body weights, food intake, food efficiency, and liver weight were observed among the three groups of rats (Table 4).

Table 4. Initial and final body weights, food intake, food efficiency, and tissue weight in rats fed the experimental diets for 5 weeks.

\begin{tabular}{cccc}
\hline & C & SE & FSE \\
\hline Initial body weight (g) & $270.5 \pm 2.3^{\mathrm{a}}$ & $272.1 \pm 2.3^{\mathrm{a}}$ & $273.5 \pm 3.3^{\mathrm{a}}$ \\
Final body weight (g) & $422.4 \pm 6.5^{\mathrm{a}}$ & $435.7 \pm 7.9^{\mathrm{a}}$ & $429.4 \pm 7.5^{\mathrm{a}}$ \\
Food intake (g/day) & $19.8 \pm 0.7^{\mathrm{a}}$ & $21.2 \pm 0.6^{\mathrm{a}}$ & $20.2 \pm 0.7^{\mathrm{a}}$ \\
$\quad \begin{array}{l}\text { Food efficiency } \\
\text { (gb.w. gain/g diet) }\end{array}$ & $0.24 \pm 0.01^{\mathrm{a}}$ & $0.24 \pm 0.01^{\mathrm{a}}$ & $0.24 \pm 0.01^{\mathrm{a}}$ \\
Tissue weight $(\%$ b.w.) Liver & $3.4 \pm 0.1^{\mathrm{a}}$ & $3.5 \pm 0.1^{\mathrm{a}}$ & $3.5 \pm 0.1^{\mathrm{a}}$ \\
\hline
\end{tabular}

Each value is the mean \pm standard error for six rats. ${ }^{a}$ Means sharing a common superscript does not differ significantly according to Tukey's multiple comparison test $(p<0.05)$. 


\subsection{Hepatic Lipid Levels}

The hepatic cholesterol and TG levels in the SE and FSE groups did not differ from those in the $\mathrm{C}$ group (Figure 1).

\subsection{Plasma Lipid Levels}

There were no significant differences in plasma TC and TG levels among the three groups (Table 5).

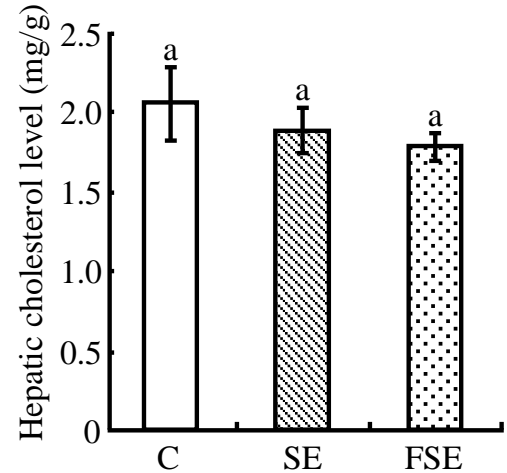

(a)

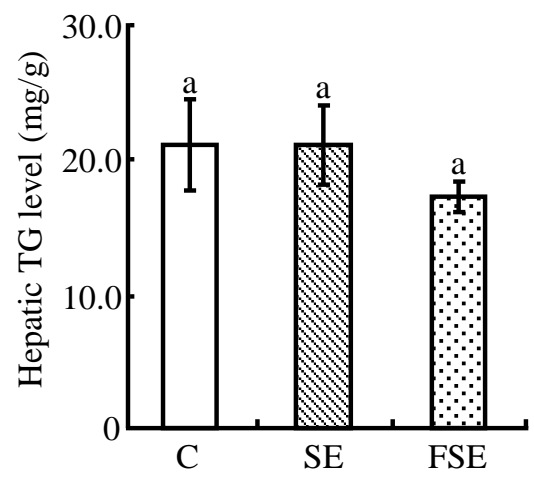

(b)

Figure 1. Hepatic parameters of rats fed the experimental diets for 5 weeks. (a) Hepatic cholesterol; (b) hepatic TG. Each value is the mean \pm standard error for six rats. ${ }^{a}$ Means sharing a common superscript does not differ significantly according to Tukey's multiple comparison test $(p<0.05)$.

Table 5. Plasma parameters of rats fed the experimental diets for 5 weeks.

\begin{tabular}{cccc}
\hline & C & SE & FSE \\
\hline Total cholesterol $(\mathrm{mmol} / \mathrm{L})$ & & & \\
0W & $1.66 \pm 0.07^{\mathrm{a}}$ & $1.65 \pm 0.16^{\mathrm{a}}$ & $1.68 \pm 0.19^{\mathrm{a}}$ \\
1W & $1.41 \pm 0.07^{\mathrm{a}}$ & $1.25 \pm 0.13^{\mathrm{a}}$ & $1.28 \pm 0.19^{\mathrm{a}}$ \\
2W & $1.47 \pm 0.06^{\mathrm{a}}$ & $1.25 \pm 0.14^{\mathrm{a}}$ & $1.29 \pm 0.17^{\mathrm{a}}$ \\
3W & $1.72 \pm 0.07^{\mathrm{a}}$ & $1.52 \pm 0.17^{\mathrm{a}}$ & $1.53 \pm 0.17^{\mathrm{a}}$ \\
4W & $1.92 \pm 0.08^{\mathrm{a}}$ & $1.66 \pm 0.17^{\mathrm{a}}$ & $1.67 \pm 0.22^{\mathrm{a}}$ \\
5W & $2.08 \pm 0.07^{\mathrm{a}}$ & $1.74 \pm 0.16^{\mathrm{a}}$ & $1.75 \pm 0.23^{\mathrm{a}}$ \\
Triglyceride $(\mathrm{mmol} / \mathrm{L})$ & & & $0.79 \pm 0.13^{\mathrm{a}}$ \\
0W & $0.67 \pm 0.05^{\mathrm{a}}$ & $0.72 \pm 0.07^{\mathrm{a}}$ & $1.11 \pm 0.21^{\mathrm{a}}$ \\
1W & $0.91 \pm 0.10^{\mathrm{a}}$ & $0.95 \pm 0.13^{\mathrm{a}}$ & $1.11 \pm 0.15^{\mathrm{a}}$ \\
2W & $0.88 \pm 0.13^{\mathrm{a}}$ & $0.95 \pm 0.16^{\mathrm{a}}$ & $1.12 \pm 0.23^{\mathrm{a}}$ \\
3W & $1.12 \pm 0.15^{\mathrm{a}}$ & $1.10 \pm 0.23^{\mathrm{a}}$ & $0.99 \pm 0.15^{\mathrm{a}}$ \\
4W & $0.81 \pm 0.05^{\mathrm{a}}$ & $1.02 \pm 0.25^{\mathrm{a}}$ & $1.39 \pm 0.22^{\mathrm{a}}$ \\
\hline 5W & $1.28 \pm 0.27^{\mathrm{a}}$ & $1.25 \pm 0.26^{\mathrm{a}}$ & \\
\hline
\end{tabular}

Each value is the mean \pm standard error for six rats. ${ }^{a}$ Means sharing a common superscript does not differ significantly according to Tukey's multiple comparison test $(p<0.05)$. 


\subsection{Real Time RT-PCR Analysis of Rat Liver}

Expression levels of genes in the cholesterol and fatty acid metabolic pathways are shown in Figure 2. After the 5-week diet period, expression of the gene encoding CYP7a1, a rate-limiting enzyme during the formation of bile acid from cholesterol, was upregulated in the FSE group relative to the $\mathrm{C}$ and SE groups. Although the expression of the gene encoding SREBP-2, which is upstream of HMG-CR, was upregulated in the FSE group relative to the $\mathrm{C}$ group, expression of the gene encoding HMG-CR, a ratelimiting enzyme in the cholesterol synthesis pathway, was not significantly upregulated in the SE and FSE groups. Similarly, although expression of the gene encoding LXR $\alpha$, which is upstream of SREBP-1, was upregulated in the SE and FSE groups relative to the $C$ group, expression levels of the genes encoding SREBP-1 and the fatty acid synthesis-related molecules FAS and ACC were not significantly upregulated in the SE and FSE groups.

\subsection{Real Time RT-PCR Analysis of HepG2 Cells}

\section{Effect of Isoflavone on Lipid Metabolism-Related Gene Expression in the} HepG2 Cell Line

Soymilk and fermented soymilk are rich in isoflavones, especially daidzein and genistein.

(a) CYP7al

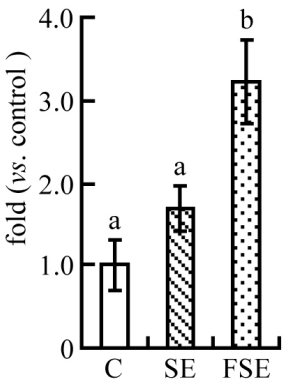

(e) SREBP-1 (b) SREBP-2

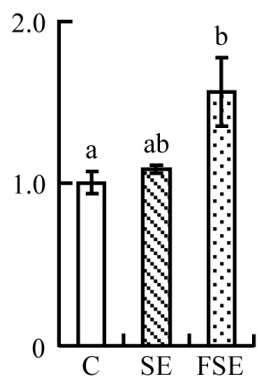

(f) $\mathrm{ACC}$ (c) $\mathrm{HMG}-\mathrm{CR}$

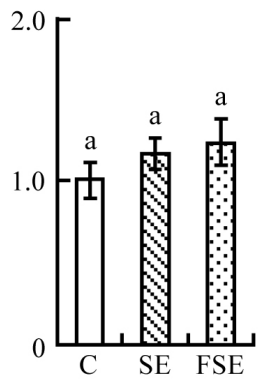

(g) LXR $\alpha$ (d) FAS

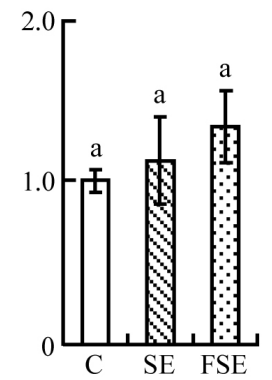

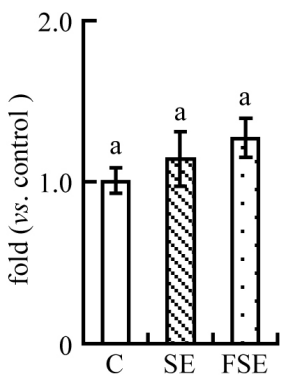
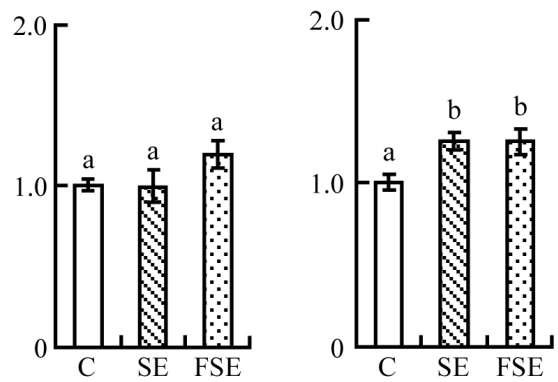

Figure 2. Expression of lipid metabolism-related genes in the livers of rats fed experimental diets for 5 weeks. mRNA was quantitatively measured by real-time RT-PCR. (a) CYP7a1; (b) SREBP-2; (c) HMG-CR; (d) FAS; (e) SREBP-1; (f) ACC; (g) LXR $\alpha$. Each value is the mean \pm standard error for six rats. Data were normalized to GAPDH RNA expression and are presented as ratios relative to the $\mathrm{C}$ value. ${ }^{\mathrm{a}, \mathrm{b}}$ Means not sharing a common superscript differ significantly according to Tukey's multiple comparison test $(p<0.05)$. 
Accordingly, we investigated the effects of isoflavones, especially daidzein and genistein, on lipid metabolism-related gene expression in HepG2 cells. In our previous paper, the hepatic isoflavone concentrations were approximately $10-20 \mu \mathrm{mol} / \mathrm{kg}$ tissue [18][21]. When rats were fed a FSE diet for 1 week, as shown in the present study, the hepatic isoflavone concentration was $10.3 \mu \mathrm{mol} / \mathrm{kg}$ tissue (Table 6). Therefore, we used 10 $\mu \mathrm{M}$ and $20 \mu \mathrm{M}$ daidzein and genstein in medium for the cell culture experiment, respectively. These isoflavone concentrations corresponded to approximately $1 / 100$ th of that in the animal experiment diet used in the present study (Table 2).

At both concentrations, daidzein and genistein upregulated the expression of the gene encoding CYP7a1 relative to the control (Figure 3). Notably, we observed no differences between $10 \mu \mathrm{M}$ and $20 \mu \mathrm{M}$ daidzein and genistein, respectively. On the other hand, SREBP-2-encoding gene expression was downregulated at $10 \mu \mathrm{M}$ and $20 \mu \mathrm{M}$ daidzein and genistein.

Although the SREBP-1-encoding gene expression was downregulated in response to $10 \mu \mathrm{M}$ and $20 \mu \mathrm{M}$ daidzein and genistein, expression of the gene encoding FAS was not affected by either isoflavone. Expression of the gene encoding $\operatorname{LXR} \alpha$, which is upstream of SREBP-1 and SREBP-2, was also upregulated in response to both isoflavones. Expression of the gene encoding LDLR was also upregulated under all conditions except daidzein at $10 \mu \mathrm{M}$.

\subsection{Effects of Soymilk and Fermented Soymilk Oligopeptides on Lipid Metabolism-Related Gene Expression in HepG2 Cells}

\subsubsection{Separation of Oligopeptides $<1 \mathrm{kDa}$}

No significant difference in the amount of crude peptides were observed between soymilk and fermented soymilk. Both soymilk and fermented soymilk contained nearly the same amounts of peptides (Table 7). These oligopeptide fractions did not contain isoflavones (data not shown).

\subsubsection{Effect of Soymilk and Fermented Soymilk Oligopeptides on Lipid Metabolism-Related Gene Expression in HepG2 Cells}

Next, we investigated the effect of oligopeptides on lipid metabolism-related gene expression. As the isoflavone concentration used for treatment was approximately $1 / 100^{\text {th }}$ of that in the animal experiment diet, the amount of oligopeptides used for treatment was adjusted to yield the same isoflavone/oligopeptide ratio found in the ethanol extract. S2 and S4 were treated with $2 \mathrm{mg}$ and $4 \mathrm{mg}$ of soymilk oligopeptide/100ml,

Table 6. Hepatic levels of isoflavones in rats fed the experimental diets.

\begin{tabular}{ccc}
\hline & SE & FSE \\
\hline Genistein $(\mu \mathrm{mol} / \mathrm{kg})$ & $0.9 \pm 0.4$ & $2.4 \pm 0.6$ \\
Daidzein $(\mu \mathrm{mol} / \mathrm{kg})$ & $2.6 \pm 0.6$ & $3.1 \pm 0.8$ \\
Equol $(\mu \mathrm{mol} / \mathrm{kg})$ & $3.5 \pm 1.3$ & $4.9 \pm 1.5$ \\
Total isoflavone $(\mu \mathrm{mol} / \mathrm{kg})$ & $7.0 \pm 1.5$ & $10.3 \pm 0.6$ \\
\hline
\end{tabular}

Each value is the mean \pm standard error for six rat. 
Table 7. Separation of peptides from soymilk and fermented soymilk extracts.

\begin{tabular}{ccc}
\hline Ingredient & \multicolumn{2}{c}{ Peptide } \\
\cline { 2 - 3 } & SE & FSE \\
\hline Crude peptide faction $(\mathrm{mg} / \mathrm{ml})$ & 11.1 & 11.9 \\
Less than MW 1 kDa fraction $(\mathrm{mg} / \mathrm{ml})$ & 5.5 & 5.7 \\
Yield $(\%)$ & 50 & 48 \\
\hline
\end{tabular}

(a) CYP7al

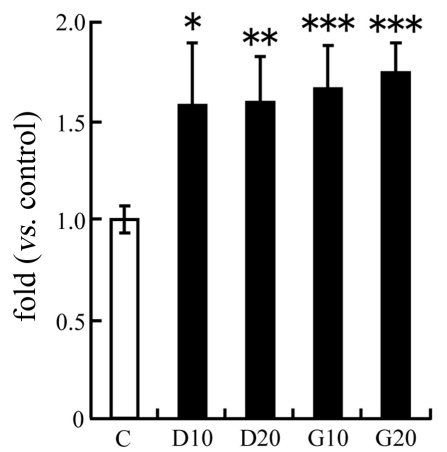

(d) SREBP-1

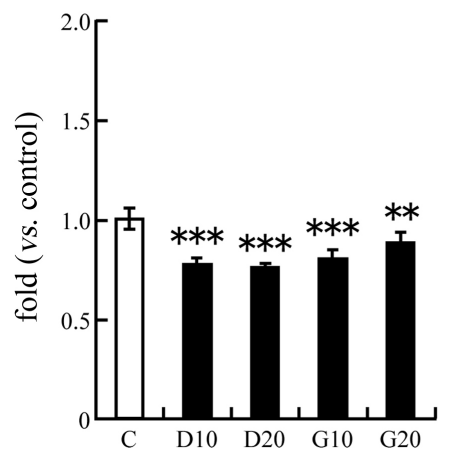

(b) FAS

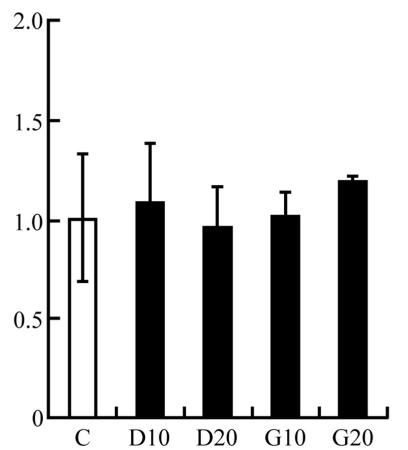

(e) $\operatorname{LXR} \alpha$

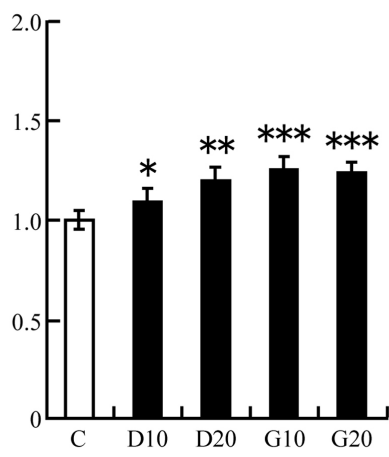

(c) SREBP-2

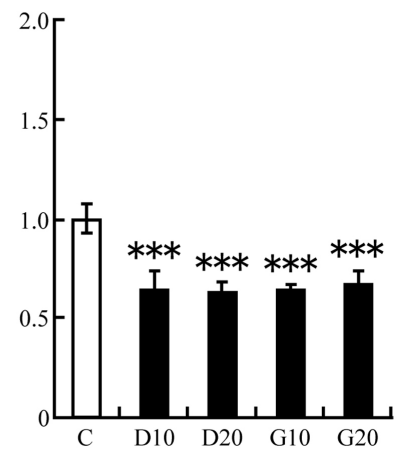

(f) LDLR

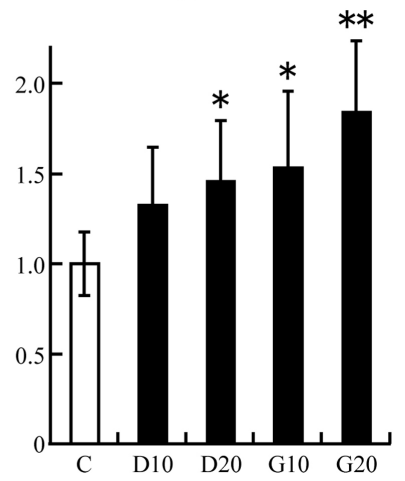

Figure 3. Effects of isoflavones on lipid metabolism-related gene expression in HepG2 cells. mRNA expression was quantitatively measured by real-time RT-PCR. Cells were treated for $24 \mathrm{~h}$ with $10 \mu \mathrm{M}$ daidzein (D10), $20 \mu \mathrm{M}$ daidzein (D20), $10 \mu \mathrm{M}$ genistein (G10), and $20 \mu \mathrm{M}$ genistein (G20). (a) CYP7a1; (b) FAS; (c) SREBP-2; (d) SREBP-1; (e) LXR $\alpha$; (f) LDLR. Each value is shown as the mean \pm standard deviation. Data were normalized to GAPDH. RNA expression levels are presented as ratios relative to the vehicle control value. ${ }^{* *} p<0.001,{ }^{* *} p<0.01,{ }^{*} p<0.05$ compared with the vehicle control; Student's $t$-test $(n=5)$.

respectively. F2 and F4 were treated with $2 \mathrm{mg}$ and $4 \mathrm{mg}$ of fermented soymilk oligopeptide/100ml, respectively.

Both soymilk and fermented soymilk oligopeptides downregulated the gene expression of CYP7a1 relative to the control (Figure 4). In particular, stronger downregulation was observed with fermented soymilk oligopeptide than with soymilk oligopeptide in a dose-dependent manner. Additionally, the gene expression of SREBP-2 was also downregulated by both soymilk and fermented soymilk oligopeptides in a dose-dependent manner. However, only fermented soymilk oligopeptides downregulated the 
(a) CYP7al

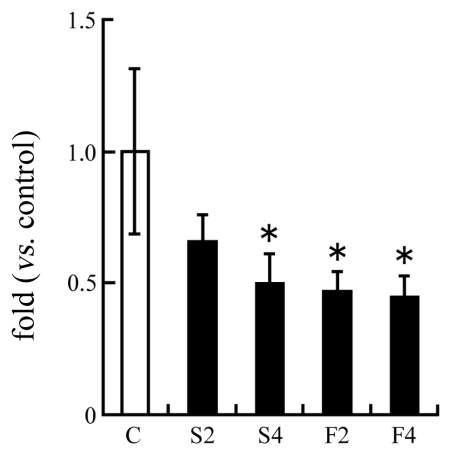

(d) SREBP-1

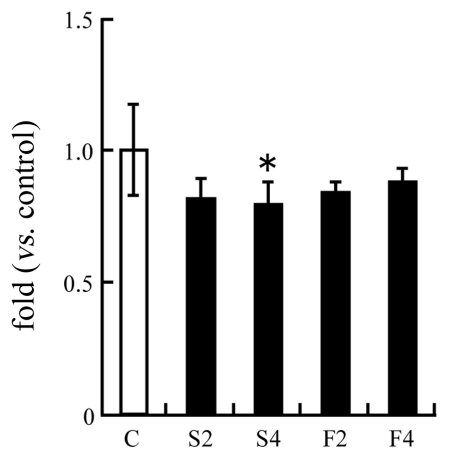

(b) FAS

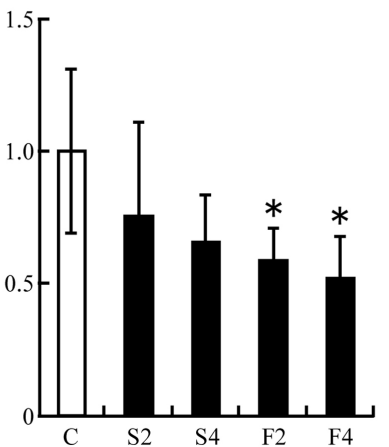

(e) $\operatorname{LXR} \alpha$

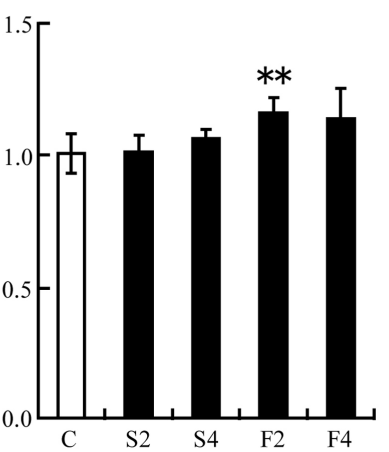

(c) SREBP-2

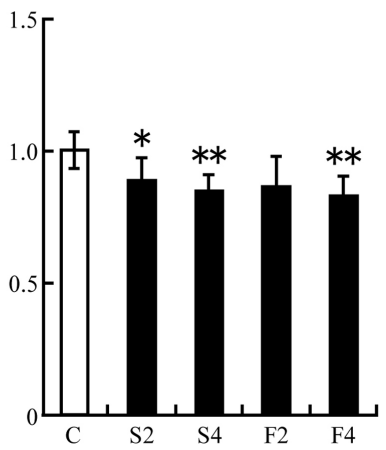

(f) LDLR

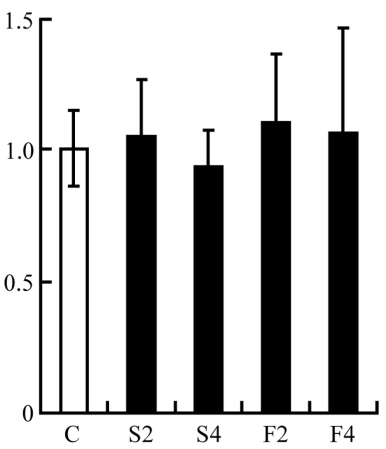

Figure 4. Effects of soymilk and fermented soymilk oligopeptides on lipid metabolism-related gene expression in HepG2 cells. mRNA expression of mRNA was quantitatively measured via real-time RT-PCR. The cells were treated for $24 \mathrm{~h}$ with $2 \mathrm{mg} / 100 \mathrm{ml}$ soymilk oligopeptides (S2), 4 $\mathrm{mg} / 100 \mathrm{ml}$ soymilk oligopeptides (S4), $2 \mathrm{mg} / 100 \mathrm{ml}$ fermented soymilk oligopeptides (F2), or 4 $\mathrm{mg} / 100 \mathrm{ml}$ fermented soymilk oligopeptides (F4). (a) CYP7a1; (b) FAS; (c) SREBP-2; (d) SREBP1; (e) LXR $\alpha$; (f) LDLR. Each value is shown as the mean \pm standard deviation. Data were normalized to GAPDH RNA expression and are presented as ratios relative to the control value. ${ }^{* *} p<$ $0.01,{ }^{\star} p<0.05$ indicate statistical significance compared with the control group; Student's $t$-test $(\mathrm{n}=5)$.

gene expression of FAS in a dose-dependent manner. The gene expression of SREBP-1 was only downregulated in the S4 culture. The gene expression of LXR $\alpha$ was upregulated only in the F2 culture. The gene expression of LDLR was not affected by oligopeptides from either soymilk or fermented soymilk.

\subsubsection{Effect of Soymilk and Fermented Soymilk Isoflavones and Oligopeptides on Lipid Metabolism-Related Gene Expression in HepG2 Cells}

The influence of cooperation between isoflavones and oligopeptides with regard to lipid metabolism-related gene expression, especially FAS and CYP7a1, was investigated. Because the hepatic daidzein/genistein ratio of the FSE diet was approximately 1:1 (Table 6), the same daidzein/genistein ratio was used in this experiment.

Although isoflavones upregulated the gene expression of CYP7a1, co-treatment with isoflavones and oligopeptides resulted in cross-cancelation of each agent's effect on the gene expression of CYP7a1. On the other hand, although the gene expression of FAS was not affected by isoflavones, co-treatment with isoflavones and oligopeptides down- 
regulated the gene expression of FAS because of the strong downregulating activity of the oligopeptides.

\section{Discussion}

Isoflavone and peptides are major functional components of fermented soymilk. Isoflavone aglycones appear to be more physiologically active than isoflavone glycosides. Compared with soymilk, fermented soymilk contains a greater amount of isoflavone aglycones (Table 2). The physiological properties of peptides in fermented soymilk are not yet known. First, we investigated the effects of FSE on hepatic lipid metabolism-related gene expression in rats fed an AIN-93G diet. Secondly, we investigated the effects of isoflavones and oligopeptides on lipid metabolism-related gene expression in HepG2 cells.

Although the hepatic cholesterol, TG, and plasma TC levels were significantly lower in the intact fermented soymilk-fed rats [17], FSE did not affect the hepatic and plasma lipid profiles (Figure 1 and Table 5). These data suggest that FSE alone does not reduce the hepatic and plasma lipid levels of rats fed an AIN-93G diet.

However, significant changes in lipid metabolism-related gene expression were observed in the livers of FSE-fed rats. Upregulated hepatic expression of the gene encoding CYP7a1, a rate-limiting enzyme in the synthesis of bile acid from cholesterol [45] that is controlled by LXR $\alpha$ [46] [47], was more strongly induced in the FSE group relative to the C and SE groups (Figure 2). Hepatic CYP7a1 expression in the FSE group was stimulated by an increase in LXR $\alpha$ expression [47]. In contrast, this expression was only slightly increased in the SE group relative to the $\mathrm{C}$ group. In our previous studies, hepatic CYP7a1 expression increased significantly in rats fed fermented soymilk plus an AIN-93G diet [17], high-cholesterol diet [18], high-fat diet [19], or high-fat and highcholesterol diet [20] [21]. Additionally, we reported that fermented soymilk, which contains a higher concentration of isoflavone aglycones, enhanced the gene expression of CYP7a1 relative to fermented soymilk with a lower concentration of isoflavone aglycones [21]. As FSE has a higher isoflavone aglycone concentration relative to SE, FSE upregulated the gene expression of CYP7a1 whereas SE scarcely had an effect on the same gene. The gene expression of SREBP-2 was also upregulated in response to FSE. These data indicate that upregulated CYP7a1 gene expression stimulated SREBP-2 gene expression and thus cholesterol homeostasis [48]. However, the gene expression of HMG-CR, a rate-limiting enzyme in the cholesterol synthesis pathway controlled by SREBP-2 [49], was not affected. It appears that either changes in downstream gene expression lagged behind those in upstream gene expression or that the mature form of SREBP-2 was downregulated. These results indicate that fermented soymilk, which is rich in isoflavone aglycones, promotes not only cholesterol catabolism but also cholesterol synthesis-related gene expression. Although the gene expression of $\operatorname{LXR} \alpha$, which is upstream of SREBP-2, significantly increased in the SE and FSE groups, the gene expression of FAS, SREBP-1, and ACC, which are downstream, did not significantly increase in either group. Accordingly, there was no significant difference in the plasma 
and hepatic lipid profiles of rats fed SE and FSE diets. Inoue et al., found a hypotriglyceridemic peptide derived from soy protein in HepG2 cells and rats [40]. In the present animal experiment, the effect of FSE on reduction of fat synthesis in rats did not appear because of insufficient amount of peptides derived from digestion of soy protein.

However, if FSE contains both enough amounts of isoflavone aglycones and oligopeptides, it is postulated that these functional components individually can affect the expression of lipid metabolism-related genes. In our second experiment, we attempted to confirm whether isoflavone aglycones and oligopeptides contained in FSE would individually affect lipid metabolism-related gene expression in the HepG2 cell line.

We investigated the effect of isoflavone aglycones, particularly daidzein and genistein, on lipid metabolism-related gene expression in HepG2 cells. Daidzein and genistein upregulated the gene expression of CYP7al (Figure 3). Although it was reported that the expression of human CYP7a1, in contrast to rat CYP7a1, is not stimulated by LXR $\alpha$ [47], CYP7a1 and LXR $\alpha$ expressions in HepG2 cells was simultaneously accelerated in the present experiment (Figure 3). As isoflavone aglycones upregulated CYP7a1 expression in HepG2 cells, a signal transduction activated by a transcriptional control element other than LXR $\alpha$ might have mediated this upregulation. Although isoflavone aglycones were found to upregulate the gene expression of SREBP-2 in HepG2 cells [50], treatment with isoflavone aglycones reduced the gene expression of SREBP-2 in our experiment (Figure 3). SREBP-2 gene expression has been shown to increase in response to decreasing intracellular cholesterol levels [48]. Therefore, isoflavone aglycones are thought to upregulate the gene expression of CYP7a1 while maintaining SREBP-2 gene expression at a low level in response to a sufficient intracellular cholesterol level. In the present experiment, although FSE tended to increase FAS gene expression (Figure 2), isoflavone aglycones did not affect FAS gene expression in HepG2 cells. Notably, isoflavone aglycone treatment downregulated the gene expression of SREBP-1, which is upstream of FAS. Because FAS gene expression decreases in response to isoflavone aglycones [51], isoflavone aglycones are thought to reduce the expression of fatty acid synthesis-related genes. LDLR gene expression increased in response to isoflavone aglycone treatment (Figure 3) [52]. Additionally, although the gene expressions of LXR $\alpha$, which is upstream of SREBP-1 [46] [51], and SREBP-1 were inclined to be increased in rats by isoflavone aglycones-containing fraction, the gene expression of SREBP-1 was decreased by isoflavone aglycones to compensate for the effect of increased LXR $\alpha$ gene expression in HepG2 cells [53].

Next, we investigated the effects of oligopeptides isolated from SE or FSE on lipid metabolism-related gene expression in HepG2 cells. Oligopeptides from both soymilk and fermented soymilk significantly downregulated the gene expression of CYP7al and SREBP-2 (Figure 4). As indicated by an earlier report in which two peptides from soy $\beta$-conglycinin increased SREBP-2 protein expression in HepG2 cells, peptide-mediated downregulation of SREBP2 seems to depend on the type of soy peptide [54]. This finding suggests that these oligopeptides suppress both the cholesterol catabolism and synthesis pathways. FAS gene expression was significantly downregulated in response to 
fermented soymilk oligopeptides, whereas soymilk oligopeptides only tended to downregulate the expression of this gene $(p<0.1$; Figure 4$)$. Lactic fermentation was thought to convert soymilk oligopeptides to more active forms. Peptides produced from soy protein by microbial proteases tend to downregulate CYP7a1 and FAS expression in rats [55]. SREBP-1 gene expression was hardly affected by either soymilk or fermented soymilk oligopeptides. These results indicate that CYP7a1 expression is promoted by isoflavone aglycones, rather than soy oligopeptides and that fatty acid synthesis-related gene expression is mainly suppressed by soy oligopeptides.

Additionally, because both oligopeptides and isoflavones downregulated SREBP-2 expression in HepG2 cells, an unknown component in the FSE fed to rats might upregulate hepatic SREBP-2 expression for functions other than hepatic cholesterol homeostasis (Figure 2).

Moreover, to confirm the interaction between isoflavone aglycones and oligopeptides, the cooperative effects of these fermented soymilk components on lipid metabolism-related gene expression were investigated. Although a mixture of daidzein and genistein significantly upregulated the gene expression of CYP7a1, this upregulation was reduced in response to co-treatment with isoflavone aglycones and oligopeptides (Figure 5). Although FAS gene expression was not affected by isoflavone aglycones alone,

(a) CYP7al

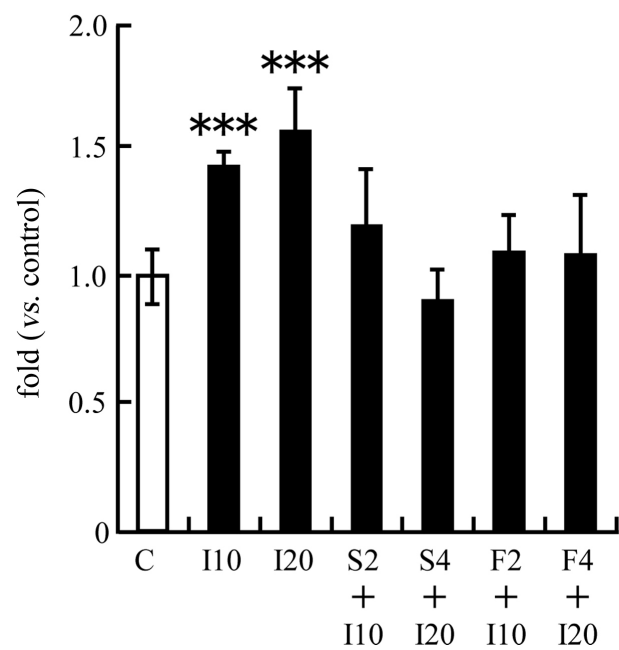

(b) FAS

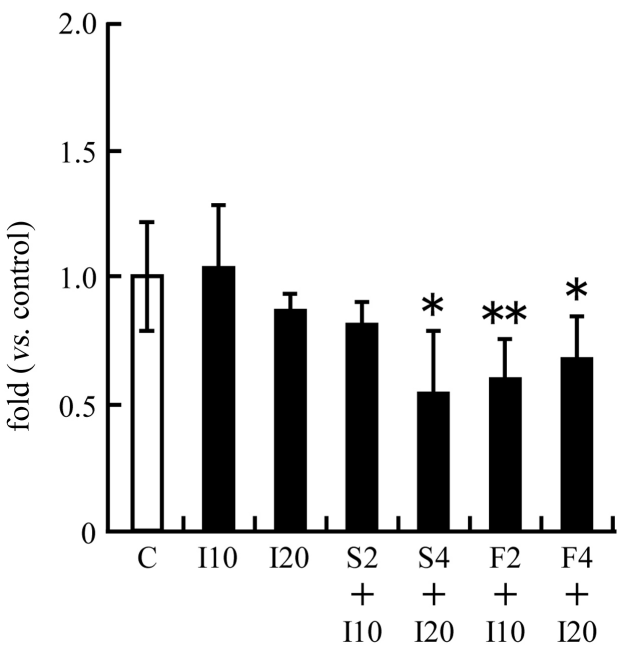

Figure 5. Effects of soymilk or fermented soymilk oligopeptides and isoflavones on lipid metabolism-related gene expression in HepG2 cells. mRNA expression was quantitatively measured by real-time RT-PCR. The cells were treated for $24 \mathrm{~h}$ with total $10 \mu \mathrm{M}$ isoflavone (daidzein + genistein) (I10), total $20 \mu \mathrm{M}$ isoflavone (daidzein + genistein) (I20), $2 \mathrm{mg} / 100 \mathrm{ml}$ soy peptide + total $10 \mu \mathrm{M}$ isoflavone (daidzein + genistein) $(\mathrm{S} 2+\mathrm{I} 10), 4 \mathrm{mg} / 100 \mathrm{ml}$ soy peptide + total $20 \mu \mathrm{M}$ isoflavone (daidzein + genistein) $(\mathrm{S} 4+\mathrm{I} 20), 2 \mathrm{mg} / 100 \mathrm{ml}$ fermented soymilk peptide + total $10 \mu \mathrm{M}$ isoflavone (daidzein + genistein) $(\mathrm{F} 2+\mathrm{I} 10)$, and $4 \mathrm{mg} / 100 \mathrm{ml}$ fermented soymilk peptide + total $20 \mu \mathrm{M}$ isoflavone (daidzein + genistein) (F4 + I20). (a) CYP7al; (b) FAS. Each value is shown as the mean \pm standard deviation. Data were normalized to GAPDH RNA expression and are presented as ratios relative to the vehicle control value. ${ }^{* *} p<0.001,{ }^{* *} p<0.01,{ }^{*} p<0.05$ indicate statistical significance compared with the control group; Student's $t$-test $(\mathrm{n}=5)$. 
co-treatment with isoflavone aglycones and oligopeptides reduced this expression. The present cell culture experiment was unable to determine differences in the intestinal absorption rates of isoflavone aglycones and oligopeptides. Because isoflavone aglycones and oligopeptides have approximate molecular weights of $250 \mathrm{Da}$ and $0.3-1$ $\mathrm{kDa}$, respectively, isoflavone aglycones are assumed to have a higher absorption rate. Without considering the absorption rate, might be stronger than that of isoflavone aglycones. Therefore, isoflavone aglycone-mediated CYP7a1 upregulation would be suppressed by co-treatment with oligopeptides. Additionally, FAS gene expression decreased in response to co-treatment with oligopeptides and isoflavone aglycones. These results indicate that both isoflavone aglycones and oligopeptides affect lipid metabolism-related gene expression and that both components play different roles and modulate each other's effects on lipid metabolism, as shown in Figure 6.

\section{Conclusion}

Isoflavone glycosides and proteins in soymilk were converted to isoflavone aglycones and oligopeptides by lactic acid fermentation, respectively. CYP7a1 gene expression was upregulated in response to isoflavone aglycones but downregulated in response to oligopeptides. FAS gene expression was downregulated in response to oligopeptides but was not affected by isoflavone aglycones. Therefore, it was found that isoflavone aglycones and oligopeptides in fermented soymilk differentially regulate hepatic lipid metabolism-related gene expression. Although the amino-acid sequences of oligopeptides produced from soymilk by lactic acid fermentation have not been clarified, we will elucidate it in the future. In addition, functional substances other than isoflavone aglycones, and soy oligopeptides in fermented soymilk might be involved in the modulation of lipid metabolism. The consumption of fermented soymilk containing isoflavone aglycones and soy peptides might prevent dyslipidemia more effectively than any other soy food. Fermented soymilk is a superior functional food modulating lipid metabolism.

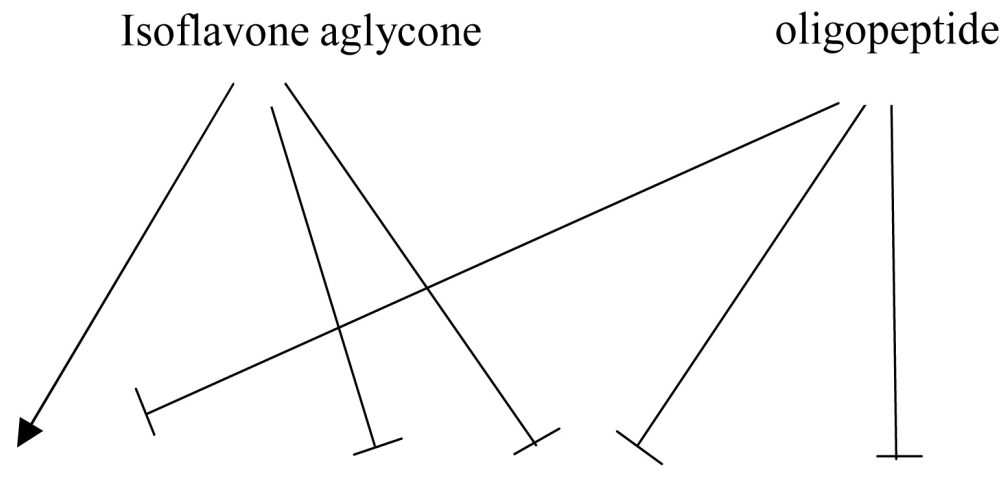

\section{$\begin{array}{llll}\text { CYP7a1 } & \text { SREBP-1 } & \text { SREBP-2 } & \text { FAS }\end{array}$}

Figure 6. Effects of isoflavones and oligopeptides in fermented soymilk on the expression of lipid metabolism-related genes (hypothesis). 


\section{Acknowledgements}

This research was supported by JSPS KAKENHI Grant Number 26750028.

\section{References}

[1] Sirtori, C.R., Lovati, M.R., Manzoni, C., Monetti, M., Pazzucconi, F. and Gatti, E. (1995) Soy and Cholesterol Reduction: Clinical Experience. Journal of Nutrition, 125, 598S-605S.

[2] Meeker, D.R. and Kesten, H.D. (1940) Experimental Atherosclerosis and High Protein Diets. Proceedings of the Society for Experimental Biology and Medicine, 45, 543-545. http://dx.doi.org/10.3181/00379727-45-11744P

[3] Nagata, Y., Ishiwaki, N. and Sugano, M. (1982) Studies on the Mechanism of Antihypercholesterolemic Action of Soy Protein and Soy Protein-Type Amino Acid Mixtures in Relation to the Casein Counterparts in Rats. Journal of Nutrition, 112, 1614-1625.

[4] Yashiro, A., Oda, S. and Sugano, M. (1985) Hypocholesterolemic Effect of Soybean Protein in Rats and Mice after Peptic Digestion. Journal of Nutrition, 115, 1325-1336.

[5] Carroll, K.K. (1991) Review of Clinical Studies on Cholesterol-Lowering Response to Soy Protein. Journal of the American Dietetic Association, 91, 820-827.

[6] Jenkins, D.J., Mirrahimi, A., Srichaikul, K., Berryman, C.E., Wang, L., Carleton, A., Abdulnour, S., Sievenpiper, J.L., Kendall, C.W. and Kris-Etherton, P.M. (2010) Soy Protein Reduces Serum Cholesterol by Both Intrinsic and Food Displacement Mechanisms. Journal of Nutrition, 140, 2302S-2311S. http://dx.doi.org/10.3945/jn.110.124958

[7] Ørgaard, A. and Jensen, L. (2008) The Effects of Soy Isoflavones on Obesity. Experimental Biology and Medicine, 233, 1066-1080. http://dx.doi.org/10.3181/0712-MR-347

[8] Penza, M., Montani, C., Romani, A., Vignolini, P., Pampaloni, B., Tanini, A., Brandi, M.L., Alonso-Magdalena, P., Nadal, A., Ottobrini, L., Parolini, O., Bignotti, E., Calza, S., Maggi, A., Grigolato P.G. and Di. Lorenzo, D. (2006) Genistein Affects Adipose Tissue Deposition in a Dose-Dependent and Gender-Specific Manner. Endocrinology, 147, 5740-5751. http://dx.doi.org/10.1210/en.2006-0365

[9] Ae. Park, S., Choi, M.S., Cho, S.Y., Seo, J.S., Jung, U.J., Kim, M.J., Sung, M.K., Park, Y.B. and Lee, M.K. (2006) Genistein and Daidzein Modulate Hepatic Glucose and Lipid Regulating Enzyme Activities in C57BL/KsJ-db/db Mice. Life Sciences, 79, 1207-1213. http://dx.doi.org/10.1016/j.lfs.2006.03.022

[10] Takahashi, Y., Odbayar, T.O. and Ide, T.A. (2009) Comparative Analysis of Genistein and Daidzein in Affecting Lipid Metabolism in Rat Liver. Journal of Clinical Biochemistry and Nutrition, 44, 223-230. http://dx.doi.org/10.3164/jcbn.08-211

[11] Goodman-Gruen, D. and Kritz-Silverstein, D. (2001) Usual Dietary Isoflavone Intake Is Associated with Cardiovascular Disease Risk Factors in Postmenopausal Women. Journal of Nutrition, 131, 1202-1206.

[12] Zhuo, X.G., Melby, M.K. and Watanabe, S. (2004) Soy Isoflavone Intake Lowers Serum LDL Cholesterol: A Meta-Analysis of 8 Randomized Controlled Trials in Humans. Journal of Nutrition, 134, 2395-2400.

[13] Zhan, S. and Ho, S.C. (2005) Meta-Analysis of the Effects of Soy Protein Containing Isoflavones on the Lipid Profile. American Journal of Clinical Nutrition, 81, 397-408.

[14] Taku, K., Umegaki, K., Sato, Y., Taki, Y., Endoh, K. and Watanabe, S. (2007) Soy Isoflavones Lower Serum Total and LDL Cholesterol in Humans: A Meta-Analysis of 11 Randomized Controlled Trials. American Journal of Clinical Nutrition, 85, 1148-1156.

[15] Chun, J., Kim, G.M., Lee, K.W., Choi, I.D., Kwon, G.H., Park, J.Y., Jeong, S.J., Kim, J.S. and 
Kim, J.H. (2007) Conversion of Isoflavone Glucosides to Aglycones in Soymilk by Fermentation with Lactic Acid Bacteria. Journal of Food Science, 72, M39-M44.

http://dx.doi.org/10.1111/j.1750-3841.2007.00276.x

[16] Izumi, T., Piskula, M.K., Osawa, S., Obata, A., Tobe, K., Saito, M., Kataoka, S., Kubota, Y. and Kikuchi, M. (2000) Soy Isoflavone Aglycones Are Absorbed Faster and in Higher Amounts than Their Glucosides in Humans. Journal of Nutrition, 130, 1695-1699.

[17] Kobayashi, M., Harada, T., Takagi, N., Tsuzuki, K., Sugawara, M. and Fukuda, M. (2012) Effects of Lactic Acid-Fermented Soymilk on Lipid Metabolism-Related Gene Expression in Rat Liver. Bioscience, Biotechnology, and Biochemistry, 76, 19-24. http://dx.doi.org/10.1271/bbb.100354

[18] Kobayashi, M., Hirahata, R., Egusa, S. and Fukuda, M. (2012) Hypocholesterolemic Effects of Lactic Acid-Fermented Soymilk on Rats Fed a High Cholesterol Diet. Nutrients, 4, 13041316. http://dx.doi.org/10.3390/nu4091304

[19] Hirahata, R., Kobayashi, M., Egusa, S., Sakakibara, R. and Fukuda, M. (2012) Effects of Fermented Soymilk on Lipid Metabolism in Rats Fed a High Fat Diet. Nippon Shokuhin Kagaku Kogaku Kaishi, 59, 528-532. (In Japanese) http://dx.doi.org/10.3136/nskkk.59.528

[20] Hirahata, R., Kobayashi, M., Egusa, S., Sakakibara, R. and Fukuda, M. (2013) Lactic Fermented Soymilk Improves Hepatic Lipid Metabolism in Rats Fed a High Fat and High Cholesterol Diet. Nippon Shokuhin Kagaku Kogaku Kaishi, 60, 72-79. (In Japanese) http://dx.doi.org/10.3136/nskkk.60.72

[21] Kobayashi, M., Sakakibara, R., Egusa, S. and Fukuda, M. (2013) Effects of Isoflavone Aglycone Ratio in Lactic Acid-Fermented Soymilk on Hepatic Lipid Metabolism in Rats Fed a High Fat and High Cholesterol Diet. Nippon Shokuhin Kagaku Kogaku Kaishi, 60, 509-515. (In Japanese) http://dx.doi.org/10.3136/nskkk.60.509

[22] Kobayashi, M., Egusa, S. and Fukuda, M. (2014) Isoflavone and Protein Constituents of Lactic Acid-Fermented Soy Milk Combine to Prevent Dyslipidemia in Rats Fed a High Cholesterol Diet. Nutrients, 6, 5704-5723. http://dx.doi.org/10.3390/nu6125704

[23] Erdmann, K., Cheung, B.W. and Schröder, H. (2008) The Possible Roles of Food-Derived Bioactive Peptides in Reducing the Risk of Cardiovascular Disease. Journal of Nutritional Biochemistry, 19, 643-654. http://dx.doi.org/10.1016/j.jnutbio.2007.11.010

[24] Matsufuji, H., Matsui, T., Ohshige, S., Kawasaki, T., Osajima, K. and Osajima, Y. (1995) Antihypertensive Effects of Angiotensin Fragments in SHR. Bioscience, Biotechnology, and Biochemistry, 59, 1398-1401. http://dx.doi.org/10.1271/bbb.59.1398

[25] Motoi, H. and Kodama, T. (2003) Isolation and Characterization of Angiotensin I-Converting Enzyme Inhibitory Peptides from Wheat Gliadin Hydrolysate. Nahrung, 47, 354358. http://dx.doi.org/10.1002/food.200390081

[26] Kawasaki, T., Seki, E., Osajima, K., Yoshida, M., Asada, K., Matsui, T. and Osajima, Y. (2000) Antihypertensive Effect of Valyl-Tyrosine, a Short Chain Peptide Derived from Sardine Muscle Hydrolyzate, on Mild Hypertensive Subjects. Journal of Human Hypertension, 14, 519-523. http://dx.doi.org/10.1038/sj.jhh.1001065

[27] Nagaoka, S., Futamura, Y., Miwa, K., Awano, T., Yamauchi, K., Kanamaru, Y., Tadashi, K. and Kuwata, T. (2001) Identification of Novel Hypocholesterolemic Peptides Derived from Bovine Milk Beta-Lactoglobulin. Biochemical and Biophysical Research Communications, 281, 11-17. http://dx.doi.org/10.1006/bbrc.2001.4298

[28] Morikawa, K., Kondo, I., Kanamaru, Y. and Nagaoka, S. (2007) A Novel Regulatory Pathway for Cholesterol Degradation Via Lactostatin. Biochemical and Biophysical Research Communications, 352, 697-702. http://dx.doi.org/10.1016/j.bbrc.2006.11.090 
[29] Kwak, J.H., Ahn, C.W., Park, S.H., Jung, S.U., Min, B.J., Kim, O.Y. and Lee, J.H. (2012) Weight Reduction Effects of a Black Soy Peptide Supplement in Overweight and Obese Subjects: Double Blind, Randomized, Controlled Study. Food \& Function, 10, 1019-1024. http://dx.doi.org/10.1039/c2fo10244g

[30] Zhang, H., Bartley, G.E., Mitchell, C.R., Zhang, H. and Yokoyama, W. (2011) Lower Weight Gain and Hepatic Lipid Content in Hamsters Fed High Fat Diets Supplemented with White Rice Protein, Brown Rice Protein, Soy Protein, and Their Hydrolysates. Journal of Agricultural and Food Chemistry, 59, 10927-10933. http://dx.doi.org/10.1021/jf202721z

[31] Craft, I.L., Geddes, D., Hyde, C.W., Wise, I.J. and Matthews, D.M. (1968) Absorption and Malabsorption of Glycine and Glycine Peptides in Man. Gut, 9, 425-437. http://dx.doi.org/10.1136/gut.9.4.425

[32] Adibi, S.A. (1997) The Oligopeptide Transporter (Pept-1) in Human Intestine: Biology and Function. Gastroenterology, 113, 332-340. http://dx.doi.org/10.1016/S0016-5085(97)70112-4

[33] Maebuchi, M., Samoto, M., Kohno, M., Ito, R., Koileda, T., Hirotsuka, M. and Nakabou, Y. (2007) Improvement in the Intestinal Absorption of Soy Protein by Enzymatic Digestion to Oligopeptide in Healthy Adult Men. Food Science and Technology Research, 13, 45-53. http://dx.doi.org/10.3136/fstr.13.45

[34] Kovacs-Nolan, J., Zhang, H., Ibuki, M., Nakamori, T., Yoshiura, K., Turner, P.V., Matsui, T. and Mine, Y. (2012) The PepT1-Transportable Soy Tripeptide VPY Reduces Intestinal Inflammation. Biochimica et Biophysica Acta, 1820, 1753-1763. http://dx.doi.org/10.1016/j.bbagen.2012.07.007

[35] Kagawa, K., Matsutaka, H., Fukuhama, C., Watanabe, Y. and Fujino, H. (1996) Globin Digest, Acidic Protease Hydrolysate, Inhibits Dietary Hypertriglyceridemia and Val-Val-TyrPro, One of Its Constituents, Possesses Most Superior Effect. Life Sciences, 58, 1745-1755. http://dx.doi.org/10.1016/0024-3205(96)00156-7

[36] Yoshikawa, M., Fujita, H., Matoba, N., Takenaka, Y., Yamamoto, T., Yamauchi, R., Tsuruki, H. and Takahata, K. (2000) Bioactive Peptides Derived from Food Proteins Preventing Lifestyle-Related Diseases. Biofactors, 12, 143-146. http://dx.doi.org/10.1002/biof.5520120122

[37] Chen, H.M., Muramoto, K., Yamauchi, F., Fujimoto, K. and Nokihara, K. (1998) Antioxidative Properties of Histidine-Containing Peptides Designed from peptide Fragments Found in the Digests of a Soybean Protein. Journal of Agricultural and Food Chemistry, 46, 49-53. http://dx.doi.org/10.1021/jf970649w

[38] Nishi, T., Hara, H., Asano, K. and Tomita, F. (2003) The Soybean Beta-Conglycinin Beta 51-63 Fragment Suppresses Appetite by Stimulating Cholecystokinin Release in Rats. Journal of Nutrition, 133, 2537-2542.

[39] Yamada, Y., Muraki, A., Oie, M., Kanegawa, N., Oda, A., Sawashi, Y., Kaneko, K., Yoshikawa, M., Goto, T., Takahashi, N., Kawada, T. and Ohinata, K. (2012) Soymorphin-5, a Soy-Derived $\mu$-Opioid Peptide, Decreases Glucose and Triglyceride Levels through Activating Adiponectin and PPAR $\alpha$ Systems in Diabetic KKA ${ }^{y}$ Mice. American Journal of Physiology-Endocrinology and Metabolism, 302, E433-E440.

http://dx.doi.org/10.1152/ajpendo.00161.2011

[40] Inoue, N., Nagao, K., Sakata, K., Yamano, N., Gunawardena, P.E., Han, S.Y., Matsui, T., Nakamori, T., Furuta, H., Takamatsu, K. and Yanagita, T. (2011) Screening of Soy Protein-Derived Hypotriglyceridemic Di-Peptides in Vitro and in Vivo. Lipids in Health and Disease, 10, 85. http://dx.doi.org/10.1186/1476-511X-10-85

[41] Mochizuki, Y., Maebuchi, M., Kohno, M., Hirotsuka, M., Wadahama, H., Moriyama, T., 
Kawada, T. and Urade, R. (2009) Changes in Lipid Metabolism by Soy Beta-ConglycininDerived Peptides in HepG2 Cells. Journal of Agricultural and Food Chemistry, 57, 14731480. http://dx.doi.org/10.1021/jf8031793

[42] Martinez-Villaluenga, C., Bringe, N.A., Berhow, M.A. and Gonzalez de Mejia, E. (2008) Beta-Conglycinin Embeds Active Peptides That Inhibit Lipid Accumulation in 3T3-L1 Adipocytes in Vitro. Journal of Agricultural and Food Chemistry, 56, 10533-10543. http://dx.doi.org/10.1021/jf802216b

[43] Reeves, P.G., Nielsen, F.H. and Fahey Jr., G.C. (1993) AIN-93 Purified Diets for Laboratory Rodents: Final Report of the American Institute of Nutrition ad Hoc Writing Committee on the Reformulation of the AIN-76A Rodent Diet. Journal of Nutrition, 123, 1939-1951.

[44] Folch, J., Lees, M. and Sloane Stanley, G.H. (1957) A Simple Method for the Isolation and Purification of Total Lipids from Animal Tissues. Journal of Biological Chemistry, 226, 497-509.

[45] Myant, N.B. and Mitropoulos, K.A. (1977) Cholesterol 7 Alpha-Hydroxylase. Journal of Lipid Research, 18, 135-153.

[46] Chen, J. and Raymond, K. (2006) Nuclear Receptors, Bile-Acid Detoxification, and Cholestasis. Lancet, 367, 454-456. http://dx.doi.org/10.1016/S0140-6736(06)68156-7

[47] Goodwin, B., Watson, M.A., Kim, H., Miao, J., Kemper, J.K. and Kliewer, S.A. (2003) Differential Regulation of Rat and Human CYP7A1 by the Nuclear Oxysterol Receptor Liver X Receptor-Alpha. Molecular Endocrinology, 17, 386-394.

http://dx.doi.org/10.1210/me.2002-0246

[48] Sato, R., Inoue, J., Kawabe, Y., Kodama, T., Takano, T. and Maeda, M. (1996) SterolDependent Transcriptional Regulation of Sterol Regulatory Element-Binding Protein-2. Journal of Biological Chemistry, 271, 26461-26464. http://dx.doi.org/10.1074/jbc.271.43.26461

[49] Vallett, S.M., Sanchez, H.B., Rosenfeld, J.M. and Osborne, T.F. (1996) A Direct Role for Sterol Regulatory Element Binding Protein in Activation of 3-Hydroxy-3-Methylglutaryl Coenzyme A Reductase Gene. Journal of Biological Chemistry, 271, 12247-12253. http://dx.doi.org/10.1074/jbc.271.21.12247

[50] Mullen, E., Brown, R.M., Osborne, T.F. and Shay, N.F. (2004) Soy Isoflavones Affect Sterol Regulatory Element Binding Proteins (SREBPs) and SREBP-Regulated Genes in HepG2 Cells. Journal of Nutrition, 134, 2942-2947.

[51] Shin, E.S., Lee, H.H., Cho, S.Y., Park, H.W., Lee, S.J. and Lee, T.R. (2007) Genistein Downregulates SREBP-1 Regulated Gene Expression by Inhibiting Site-1 Protease Expression in HepG2 Cells. Journal of Nutrition, 137, 1127-1131.

[52] Kirk, E.A., Sutherland, P., Wang, S.A., Chait, A. and LeBoeuf, R.C. (1998) Dietary Isoflavones Reduce Plasma Cholesterol and Atherosclerosis in C57BL/6 Mice but Not LDL Receptor-deficient Mice. Journal of Nutrition, 128, 954-959.

[53] Gonzalez-Granillo, M., Steffensen, K.R., Granados. O., Torres, N., Korach-Andre, M., Ortiz, V., Aguilar-Salinas, C., Jakobsson, T., Diaz-Villasenor, A., Loza-Valdes, A., HernandezPando, R., Gustafsson, J.A. and Tovar, A.R. (2012) Soy Protein Isoflavones Differentially Regulate Liver X Receptor Isoforms to Modulate Lipid Metabolism and Cholesterol Transport in the Liver and Intestine in Mice. Diabetologia, 55, 2469-2478.

http://dx.doi.org/10.1007/s00125-012-2599-9

[54] Lammi, C., Zanoni, C., Arnoldi, A. and Vistoli, G. (2015) Two Peptides from Soy $\beta$-Conglycinin Induce a Hypocholesterolemic Effect in HepG2 Cells by a Statin-Like Mechanism: Comparative in Vitro and in Silico Modeling Studies. Journal of Agricultural and Food 
Chemistry, 63, 7945-7951. http://dx.doi.org/10.1021/acs.jafc.5b03497

[55] Liyanage, R., Han, K.-H., Watanabe, S., Shimada, K., Sekikawa, M., Ohba, K., Tokuji, Y., Ohnishi, M., Shibayama, S., Nakamori, T. and Fukushima, M. (2008) Potato and Soy Peptide Diets Modulate Lipid Metabolism in Rats. Bioscience, Biotechnology, and Biochemistry, 72, 943-950. http://dx.doi.org/10.1271/bbb.70593

\section{Submit or recommend next manuscript to SCIRP and we will provide best service} for you:

Accepting pre-submission inquiries through Email, Facebook, LinkedIn, Twitter, etc.

A wide selection of journals (inclusive of 9 subjects, more than 200 journals)

Providing 24-hour high-quality service

User-friendly online submission system

Fair and swift peer-review system

Efficient typesetting and proofreading procedure

Display of the result of downloads and visits, as well as the number of cited articles

Maximum dissemination of your research work

Submit your manuscript at: http://papersubmission.scirp.org/

Or contact fns@scirp.org 